\title{
Purification and characterization of a novel alkaline serine protease secreted by Vibrio metschnikovii
}

\author{
JAE YEONG PARK ${ }^{1}$, JUNG EUN PARK ${ }^{1}$, JONG WOO PARK ${ }^{1}$, SEONG MYEONG YOON $^{2}$ and JUNG SUP LEE ${ }^{1}$ \\ Departments of ${ }^{1}$ Biotechnology and ${ }^{2}$ Marine Life Science, College of Natural Sciences, \\ Chosun University, Gwangju 501-759, Republic of Korea
}

Received August 2, 2011; Accepted August 29, 2011

DOI: $10.3892 /$ ijmm.2011.813

\begin{abstract}
A novel extracellular alkaline serine protease secreted by Vibrio metschnikovii (V. metschnikovii) ATCC700040 cells was purified by three chromatographic steps and characterized in terms of enzymatic kinetics and substrate specificity. The purified enzyme (named AKP-Vm) was composed of a single polypeptide with an apparent molecular weight of $50 \mathrm{kDa}$ on $12 \%$ SDS-polyacrylamide gel in the presence of $\mathrm{CuCl}_{2}$. The optimal temperature and the $\mathrm{pH}$ for the enzyme were found to be $37^{\circ} \mathrm{C}$ and 9.5 , respectively. However, the enzyme activity was inhibited by inhibitors such as PMSF and aprotinin. AKP-Vm could hydrolyze a peptide bond at the carboxyl side of the arginine residue, as revealed by its amidolytic activity toward a chromogenic substrate, Boc-Val-Pro-Arg- $p$ NA. The kinetic parameters of the enzyme were as follows: $K_{\mathrm{M}}=0.91 \mathrm{mM}$, $k_{\text {cat }}=0.8 \mathrm{sec}^{-1}$ and $k_{\text {cat }} / K_{\mathrm{M}}=0.88 \mathrm{mM}^{-1} \mathrm{sec}^{-1}$. AKP-Vm protease could cleave various blood coagulation-associated proteins, including fibrinogen, prothrombin and thrombin. In particular, the enzyme showed powerful fibrinogenolytic and fibrinolytic activities, as it could cleave all major chains of fibrinogen and also digest cross-linked fibrin. The results obtained suggest that $\mathrm{AKP}-\mathrm{Vm}$ is a novel alkaline serine protease that can actively cleave fibrinogen and cross-linked fibrin.
\end{abstract}

\section{Introduction}

The pathogenic bacteria Vibrios produce various virulent factors, including adhesin, polysaccharide, enterotoxin,

Correspondence to: Professor Jung Sup Lee, Department of Biotechnology, College of Natural Sciences, Chosun University, 375 Seosuk-dong Dong-gu, Gwangju 501-759, Republic of Korea E-mail: jsplee@chosun.ac.kr

Abbreviations: 1,10-PT, 1,10-phenanthroline; DFP, diisopropyl fluorophosphate; DTT, dithiothreitol; EDTA, ethylenediaminetetraacetic acid; EGTA, ethylene glycol-bis(2-aminoethyl ether)$\mathrm{N}, \mathrm{N}, \mathrm{N}^{\prime}, \mathrm{N}^{\prime}$-tetraacetic acid; LB, Luria-Bertani medium; PMSF, phenylmethanesulfonyl fluoride; SDS-PAGE, sodium dodecyl sulfate-polyacrylamide gel electrophoresis

Key words: Vibrio metschnikovii, extracellular alkaline serine protease, fibrinolytic enzyme, fibrinogenolytic enzyme, alkaline protease cytotoxin, hemolysin and proteases (1). In particular, extracellular proteases produced by Vibrio vulnificus (V. vulnificus), V. mimicus, and V. cholerae have been known to play various roles in bacterial infection. For example, they enhance vascular permeability through the activation of the plasma kallikrein-kinin system (2-4). An extracellular protease from $V$. fluvialis exhibits haemagglutinating and haemorrhagic activities (5). A metalloprotease (named vEP) secreted by $V$. vulnificus affects the human blood coagulation system through prothrombin activation and fibrinolysis (6).

$V$. metschnikovii is a gram-negative alkalophilic human pathogenic bacterium $(1,7,8)$. This facultative bacterium is often found in natural aquatic environments such as seawater (9). In addition, the bacterium has been known as one of causative agents that can induce dyspneic symptoms (10), diarrhea (11,12), wound infection (13), pneumonia (1) and leg ulcer (9). There have been brief reports on alkaline proteases (AprB, AprJ1, VapT and VapK) from a few V. metschnikovii strains. AprB, VapT and VapK proteases show SDS-resistance activity $(8,14-16)$ and AprJ1 exhibits a stability toward nonionic surfactant and oxidizing agents (17). However, there are no detailed studies on the biochemical properties and fibrin(ogen)olytic activity of the alkaline proteases secreted by V. metschnikovii.

In this study, we purified and characterized a novel extracellular alkaline serine protease, AKP-Vm (alkaline protease of V. metschnikovii) from V.metschnikovii ATCC700040 cells. We describe the biochemical properties of AKP-Vm in terms of its enzyme kinetics and substrate specificity toward various human blood coagulation-associated proteins including plasminogen, plasmin, fibrinogen, fibrin polymer and cross-linked fibrin.

\section{Materials and methods}

Materials. V. metschnikovii ATCC700040 cells were obtained from the Korean Culture Center of Microorganism (KCCM; Seoul, Korea). The columns HiPrep 16/10 Q FF, Source 15 Q 4.6/100 PE, Superdex 75 10/300 GL, and PD-10 were purchased from Amersham Biotech (Uppsala, Sweden). Ammonium sulfate $\left[\left(\mathrm{NH}_{4}\right)_{2} \mathrm{SO}_{4}\right]$ was from Daejung Chemicals (Siheung, Korea). The YM-10 membranes were purchased from Millipore (Billerica, MA, USA). Plasmin was from Roche Applied Science (Mannheim, Germany). Prothrombin and thrombin were obtained from Calbiochem (Daemstadt, 
Table I. Summary for the purification of AKP-Vm protease secreted by V. metschnikovii ATCC700040 cells.

\begin{tabular}{lcccc}
\hline Purification step & Total protein $(\mathrm{mg})$ & Total activity $($ units) & Specific activity $(\mathrm{U} / \mathrm{mg})^{\mathrm{a}}$ & ${\text { Yield }(\%)^{\mathrm{b}}}^{\mathrm{b}}$ \\
\hline Ammonium sulfate & 257.4 & 18,412 & 71.5 & 100 \\
HiPrep 16/10 Q FF & 21.6 & 2,922 & 135.3 & 8.4 \\
Source 15 Q 4.6/100 PE & 3.8 & 1,726 & 454.4 & 1.5 \\
Superdex 75 10/300 GL & 0.2 & 240 & 1,000 & 0.1 \\
\hline
\end{tabular}

${ }^{\mathrm{a}}$ One unit (U) was defined as the amount of enzyme that catalyzes the release of $1 \mu \mathrm{mol}$ of $p$ NA per min. ${ }^{\mathrm{b}}$ Total activity of total extracellular proteins was assigned the value of $100 \%$.

Germany). Human factor XIIIa was from Haematologic Technologies, Inc. (Essex Junction, VT, USA). Human fibrinogen, aprotinin, bestatin, EDTA, EGTA, 1,10-phenanthroline (1,10-PT), $\beta$-mercaptoethanol, PMSF, diisopropyl fluorophosphate (DFP) and DTT were from Sigma (St. Louis, MO, USA). Protein molecular weight size markers were from Fermentas GmbH (St. Leon-Rot, Germany). Synthetic chromogenic substrates, Boc-Leu-Gly-Arg- $p$ NA and Boc-Val-Pro-Arg- $p$ NA were from Seikagaku (Tokyo, Japan). Other chromogenic substrates, including Ile-Glu-(-OR)-Gly-Arg- $p$ NA (S-2222), H-D-Phe-Pip-Arg- $p$ NA (S-2238), H-D-Val-Leu-Lys- $p$ NA (S-2251), H-D-Ile-Pro-Arg-pNA (S-2288), Pyro-Glu-GlyArg- $p$ NA (S-2444) and N- $\alpha$-Z-D-Arg-Gly-Arg- $p$ NA (S-2765) were from Chromogenix (Milan, Italy).

Purification of protease. V. metschnikovii ATCC700040 cells were cultivated in $\mathrm{LB}$ medium ( $\mathrm{pH} 7.5$ ) containing $3 \% \mathrm{NaCl}$ at $30^{\circ} \mathrm{C}$, and extracellular proteins contained in the culture supernatant were fractionated by $70 \%$ ammonium sulfate in a saturation concentration. The precipitated proteins were harvested by centrifugation at $16,000 \mathrm{xg}$ for $30 \mathrm{~min}$ at $4^{\circ} \mathrm{C}$ and dissolved in $25 \mathrm{mM}$ Tris-HCl buffer ( $\mathrm{pH}$ 7.5). The proteins were desalted on a PD-10 column and applied onto a HiPrep 16/10 Q FF column equilibrated with $25 \mathrm{mM}$ Tris- $\mathrm{HCl}(\mathrm{pH} 7.5)$. The bound proteins were eluted with a linear gradient of $\mathrm{NaCl}$ $(0-0.8 \mathrm{M})$ at a flow rate of $2.0 \mathrm{ml} / \mathrm{min}$. Fractions showing proteolytic activities on an casein plate were pooled and concentrated by YM-10 membrane. The concentrated proteins were then applied onto a Source 15 Q 4.6/100 PE column equilibrated with $25 \mathrm{mM}$ Tris- $\mathrm{HCl}(\mathrm{pH} 7.5)$ and the bound proteins were eluted with a linear gradient of $\mathrm{NaCl}(0-0.5 \mathrm{M})$ at a flow rate of $1.0 \mathrm{ml} / \mathrm{min}$. Active fractions were pooled and further fractionated on a Superdex 75 10/300 GL column using $25 \mathrm{mM}$ Tris-HCl buffer (pH 7.5) containing $200 \mathrm{mM} \mathrm{NaCl}$. Active fractions were pooled, concentrated, and used as a purified enzyme. In each purification step, protein concentrations were determined with the Bradford reagent according to the manufacturer's instructions.

SDS-polyacrylamide gel electrophoresis (SDS-PAGE). SDS-PAGE was performed according to the method of Laemmli (18). Samples to be analyzed were mixed with an equal volume of $2 X$ SDS-PAGE sample buffer, boiled at $100^{\circ} \mathrm{C}$ for $2 \mathrm{~min}$, and then loaded onto the gel. After electrophoresis, protein bands were visualized by staining the gel with Coomassie Brilliant Blue as described elsewhere.
Protease activity assay. Azocasein assay was routinely used for determining protease activity in purification steps (6). In this assay, a reaction mixture (200 $\mu 1)$ consisting of enzyme to be tested and $0.25 \%$ azocasein in $50 \mathrm{mM}$ Tris- $\mathrm{HCl}$ buffer (pH 9.5) was incubated at $37^{\circ} \mathrm{C}$ for $15 \mathrm{~min}$ and the reaction was stopped by the addition of $100 \mu 1$ of $10 \%$ trichloroacetic acid. After centrifugation at 13,000 x g for $10 \mathrm{~min}$, the resulting supernatant was withdrawn and the absorbance was measured at $440 \mathrm{~nm}$. Protease activity assayed with synthetic chromogenic substrates was performed in a 96-well plate reader (Molecular Devices). Reaction mixture (total $100 \mu \mathrm{l}$ ) containing enzyme to be assayed, $0.4 \mathrm{mM}$ chromogenic substrate, $20 \mathrm{mM}$ Tris- $\mathrm{HCl}(\mathrm{pH} 9.5), 0.1 \mathrm{mg} / \mathrm{ml}$ BSA and $0.9 \% \mathrm{NaCl}$ was incubated at $37^{\circ} \mathrm{C}$ and the absorbance at $405 \mathrm{~nm}$ was continuously monitored over a period of $30 \mathrm{~min}$. One unit of protease activity was defined as the amount of enzyme that catalyzes the release of $1 \mu \mathrm{mol}$ of $p$ NA per min. The following buffer systems were used for $\mathrm{pH}$ requirement of enzyme: $20 \mathrm{mM}$ sodium acetate (pH 4.0 to 5.0$) ; 20 \mathrm{mM}$ sodium phosphate (pH 6.0 to 7.5 ); $20 \mathrm{mM}$ Tris- $\mathrm{HCl}$ (pH 8.0 to 9.0); $20 \mathrm{mM}$ glycine- $\mathrm{NaOH}$ (pH 9.5 to 11.0 ); $20 \mathrm{mM}$ sodium carbonate ( $\mathrm{pH} 11.5$ to 12.0 ).

Effect of divalent cations on heat-induced degradation of AKP-Vm. AKP-Vm enzyme were mixed with $10 \mathrm{mM}$ each of various divalent cations $\left(\mathrm{CaCl}_{2}, \mathrm{MnCl}_{2}, \mathrm{MgCl}_{2}, \mathrm{ZnCl}_{2}, \mathrm{NiCl}_{2}\right.$ and $\left.\mathrm{CuCl}_{2}\right)$ in $6 \mathrm{X}$ reducing sample buffer $(300 \mathrm{mM}$ Tris- $\mathrm{HCl}$, pH 6.8, 30\% glycerol, $10 \%$ SDS, 0.6 M DTT, and $0.012 \%$ bromphenol blue) and boiled for $2 \mathrm{~min}$ at $100^{\circ} \mathrm{C}$. The protein samples were then electrophoresed on $12 \%$ polyacrylamide gel and the protein bands were visualized by staining the gel with Coomassie Brilliant Blue as described elsewhere.

Prothrombin activation by AKP-Vm. For the detection of prothrombin activation, $200 \mu 1$ of reaction mixture $(25 \mathrm{mM}$ Tris-HCl, $\mathrm{pH} 9.5,0.4 \mathrm{mg} / \mathrm{ml}$ prothrombin, $0.5 \mu \mathrm{g}$ enzyme to be tested) was incubated at $37^{\circ} \mathrm{C}$ and $24 \mu 1$ aliquots were withdrawn at different time intervals. The reaction was stopped by the addition of $1 \mu \mathrm{l}$ of $24 \mathrm{mM} \mathrm{CuCl}$. To measure thrombin activity, $10 \mu 1$ of sample was assayed with $0.4 \mathrm{mM}$ of Boc-ValPro-Arg- $p$ NA as a substrate in $25 \mathrm{mM}$ Tris- $\mathrm{HCl}, \mathrm{pH} 7.5,0.9 \%$ $\mathrm{NaCl}, 1 \mathrm{mM} \mathrm{CuCl}{ }_{2}$ and $0.1 \mathrm{mg} / \mathrm{ml} \mathrm{BSA}$ in a $100 \mu 1$ reaction volume at $37^{\circ} \mathrm{C}$ using a $96-$ well plate reader. The increase in absorbance at $405 \mathrm{~nm}$ was recorded over a period of $10 \mathrm{~min}$. For the detection of fibrin polymerization, $10 \mu 1$ of the prothrombin digest was mixed with $190 \mu 1$ of $25 \mathrm{mM}$ Tris- $\mathrm{HCl}$ 
A
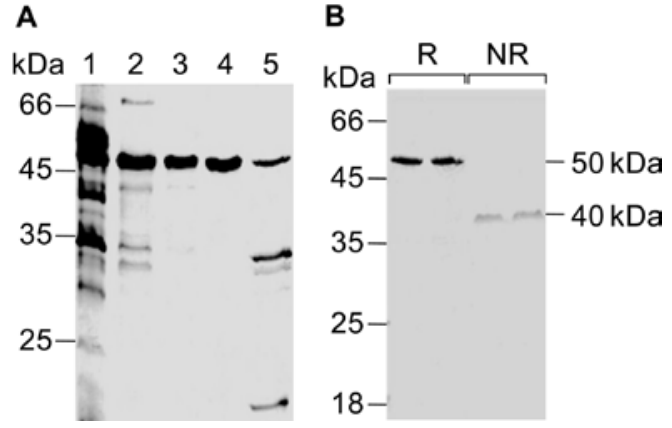

Figure 1. SDS-PAGE of purified AKP-Vm. (A) The active fraction obtained from each chromatographic step was subjected to SDS-PAGE under reducing condition. Protein samples were prepared in the presence (lanes 1-4) or absence (lane 5) of $1 \mathrm{mM}$ of $\mathrm{CuCl}_{2}$. Lanes 1, total extracellular proteins; 2, HiPrep 16/10 Q FF; 3, Source 15 Q 4.6/100; 4 and 5, Superdex 75 10/300 GL. (B) The purified enzyme was sampled under reducing (R) and non-reducing (NR) conditions as described in Materials and methods, electrophoresed on $12 \%$ polyacrylamide gel, and then stained with Coomassie Brilliant Blue for visualization.

buffer ( $\mathrm{pH} 7.5$ ) containing $100 \mu \mathrm{g}$ fibrinogen and $1 \mathrm{mM} \mathrm{CuCl}_{2}$, and the change in turbidity was measured at $350 \mathrm{~nm}$.

Fibrin(ogen)olytic activity assay of Vm-AP. To examine the fibrinogenolytic activity of AKP-Vm, human fibrinogen $(30 \mu \mathrm{g})$ was dissolved in $25 \mathrm{mM}$ Tris- $\mathrm{HCl}$ buffer $(\mathrm{pH} 9.5)$ containing $150 \mathrm{mM} \mathrm{NaCl}$ and incubated with AKP-Vm enzyme $(62.5 \mathrm{ng})$ at $37^{\circ} \mathrm{C}$ for various time periods. The reaction products were analyzed by $12 \%$ SDS-polyacrylamide gel electrophoresis. The spontaneous polymerization of fibrin monomers derived from AKP-Vm-cleaved fibrinogen was assayed by turbidity assay. In this assay, $90 \mu 1$ of $1 \mathrm{mg} / \mathrm{ml}$ fibrinogen in $25 \mathrm{mM}$ Tris-HCl buffer ( $\mathrm{pH} 7.5$ ) was mixed with $10 \mu 1$ each of thrombin $(10 \mathrm{U} / \mathrm{ml})$ and AKP-Vm $(50 \mu \mathrm{g} / \mathrm{ml})$, and the increase in absorbance at $350 \mathrm{~nm}$ was then recorded with a 96-well plate reader (Molecular Devices). For the detection of cross-linked fibrin cleavage by AKP-Vm, fibrinogen $(10 \mu \mathrm{g})$, thrombin (0.02 units) and factor XIIIa (0.03 units) were mixed in $25 \mathrm{mM}$ Tris- $\mathrm{HCl}(\mathrm{pH} \mathrm{7.5)}$ containing $150 \mathrm{mM} \mathrm{NaCl}$ and $1 \mathrm{mM} \mathrm{CaCl}_{2}$, and the mixture was incubated at room temperature for $2 \mathrm{~h}$. AKP-Vm $(0.5 \mu \mathrm{g})$ was then added to the resulting cross-linked fibrin and further incubated at $37^{\circ} \mathrm{C}$ for $5 \mathrm{~min}$. The resulting products were analyzed by $12 \%$ SDS-PAGE. Fibrinolytic activity was also measured using a fibrin plate as previously described (6).

\section{Results}

Purification of an extracellular protease from V. metschnikovii ATCC 700040 cells. An extracellular alkaline serine protease was purified from the culture supernatant of $V$. metschnikovii ATCC700040 cells. To obtain the extracellular proteins, V. metschnikovii ATCC700040 cells were cultivated overnight in $\mathrm{LB}$ medium containing $3 \% \mathrm{NaCl}$ at $30^{\circ} \mathrm{C}$, and the proteins contained in the culture medium were precipitated with ammonium sulfate in a saturation concentration of $70 \%$. The fractionated proteins were subjected to HiPrep 16/10 Q FF, Source 15 Q 4.6/100 PE, and Superdex 75 10/300 GL columns in order (data not shown), and the finally purified enzyme was named AKP-Vm. The summary of the purifica-

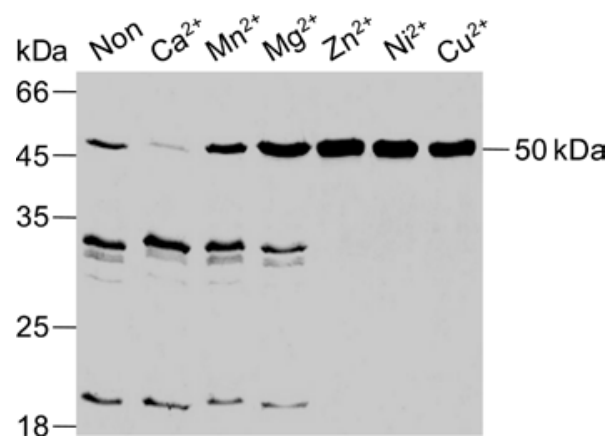

Figure 2. Effects of various divalent cations on the heat-induced degradation of AKP-Vm. Five micrograms of purified AKP-Vm enzyme were boiled at $100^{\circ} \mathrm{C}$ for $2 \mathrm{~min}$ in the absence or presence of $\mathrm{CaCl}_{2}, \mathrm{MnCl}_{2}, \mathrm{MgCl}_{2}, \mathrm{ZnCl}_{2}, \mathrm{NiCl}_{2}$ and $\mathrm{CuCl}_{2}$ as indicated and electrophoresed on $12 \%$ polyacrylamide gel under reducing condition. Non, AKP-Vm enzyme without any cation.

tion procedure is shown in Table I. About $0.2 \mathrm{mg}$ of enzyme could be obtained from 1 liter of culture supernatant. The purified enzyme showed a specific activity of $1,000 \mathrm{U} / \mathrm{mg}$ protein, which represented $\sim 14$-fold increase over the culture supernatant (Table I). Fig. 1A shows the results of SDS-PAGE with proteins obtained from each chromatographic step. The purified enzyme appeared as a single band on SDS-PAGE, having an apparent molecular mass of $50 \mathrm{kDa}$ in the presence of $1 \mathrm{mM}$ of $\mathrm{CuCl}_{2}$ (Fig. 1A, lanes 2-4). However, the enzyme was degraded into several fragments in the absence of the divalent cation (Fig. 1A, lane 5). This result suggests that the purified enzyme can be degraded by its own proteolytic activity at the boiling step for SDS-PAGE, and this heat-induced degradation can be inhibited by $\mathrm{CuCl}_{2}$. The molecular weights of purified AKP-Vm could be estimated to 50 and $40 \mathrm{kDa}$ under reducing and non-reducing conditions, respectively, in the presence of $1 \mathrm{mM} \mathrm{CuCl}_{2}$ (Fig. 1B). These results suggest that disulfide bonds located in the enzyme may play an important role in maintaining the conformation of enzyme.

Effects of divalent cations on the heat-induced degradation of AKP-Vm. As described in the previous section, AKP-Vm seemed to be degraded into several fragments at the heating step for SDS-PAGE, which could be suppressed by the addition of $\mathrm{CuCl}_{2}$. Therefore, it was necessary to examine the effects of various divalent cations on the heat-induced degradation of AKP-Vm. When the purified enzyme was incubated for $2 \mathrm{~min}$ at $100^{\circ} \mathrm{C}$ in the absence or presence of various divalent cations, the heat-induced degradation could be completely blocked by the addition of $\mathrm{ZnCl}_{2}, \mathrm{NiCl}_{2}$ and $\mathrm{CuCl}_{2}$, but not by $\mathrm{CaCl}_{2}, \mathrm{MnCl}_{2}$ and $\mathrm{MgCl}_{2}$ (Fig. 2). It seemed to be closely related to the proteolytic activity of the enzyme because the event did not occur when the enzyme was inhibited by $\mathrm{CuCl}_{2}$ and $\mathrm{NiCl}_{2}$ (Table II). Interestingly, the event also did not occur when the enzyme was incubated with $\mathrm{ZnCl}_{2}$, although the divalent cation showed no inhibitory effect on the enzyme activity (Table II). These results suggest that the heat-induced degradation occurs by the enzyme's own proteolytic activity and can be suppressed by inhibiting the enzyme activity. In addition, $\mathrm{Zn}^{2+}$ may block the suicidal activity of the enzyme by stabilizing the enzyme's conformation under high temperature to maintain its intrinsic enzyme specificity. 
Table II. Effects of various divalent cations, protease inhibitors and chemical reagents on $\mathrm{AKP}-\mathrm{Vm}$ activity.

\begin{tabular}{lcc}
\hline Additive & Concentration $(\mathrm{mM})$ & Activity $(\%)^{\mathrm{a}}$ \\
\hline Control & 0 & 100.0 \\
$\mathrm{Ni}^{2+}$ & 1 & 74.6 \\
$\mathrm{Mg}^{2+}$ & 1 & 109.4 \\
$\mathrm{Mn}^{2+}$ & 1 & 80.4 \\
$\mathrm{Cu}^{2+}$ & 1 & 29.9 \\
$\mathrm{Zn}^{2+}$ & 1 & 96.4 \\
$\mathrm{DFP}$ & 1 & 70.9 \\
PMSF & 1 & 27.4 \\
Aprotinin & 1 & 10.3 \\
Bestatin & 1 & 83.7 \\
$1,10-P T$ & 1 & 81.6 \\
EDTA & 1 & 82.1 \\
EGTA & 1 & 88.0 \\
$\beta$-mercaptoethanol & 500 & 42.6 \\
DTT & 500 & 45.1 \\
\hline
\end{tabular}

${ }^{a} \mathrm{AKP}-\mathrm{Vm}$ activity was assayed with Boc-Val-Pro-Arg- $p$ NA as a substrate with or without the corresponding additive at $37^{\circ} \mathrm{C}$ for $30 \mathrm{~min}$ in $20 \mathrm{mM}$ Tris- $\mathrm{HCl}$ (pH 9.5) as described in Materials and methods.

Amidolytic activity and kinetic parameters of AKP-Vm protease. The amidolytic activity of AKP-Vm protease was examined with various synthetic peptide substrates. Of the eight chromogenic substrates examined (Boc-Val-Pro-Arg-pNA, S-2222, S-2238, S-2251, S-2288, S-2444, S-2765, Boc-Leu-Gly-Arg- $p$ NA), Boc-Val-Pro-Arg- $p$ NA and S-2238 (H-D-Phe-Pip-Arg- $p$ NA) could be efficiently hydrolyzed by the enzyme (data not shown). However, the amidolytic activity of AKP-Vm toward S-2238 was $38 \%$ lower than that to Boc-Val-Pro-Arg- $p$ NA (data not shown). These results suggest that AKP-Vm can hydrolyze a peptide bond at the carboxyl sides of arginines in those peptide substrates, and the degree of cleavage may be affected by the sequence around the arginine residue. When Boc-Val-ProArg- $p$ NA was used as a substrate, the kinetic values of AKP-Vm were found to be as follows: $K_{\mathrm{M}}=0.91 \mathrm{mM}, k_{\text {cat }}=0.8 \mathrm{sec}^{-1}$ and $k_{\text {cat }}$ t $K_{\mathrm{M}}=0.88 \mathrm{mM}^{-1} \mathrm{sec}^{-1}$.

Enzymatic properties of AKP-Vm. The optimal temperature and the $\mathrm{pH}$ for AKP-Vm activity were found to be $37^{\circ} \mathrm{C}$ (Fig. 3A) and pH 9.5 (Fig. 3B), respectively, when Boc-Val-Pro-Arg- $p$ NA was used as a substrate. In addition, the enzyme was relatively active even at $\mathrm{pH} 12.0$ (Fig. 3B), in which $~ 65 \%$ of the enzyme activity was retained, compared to that at $\mathrm{pH}$ 9.5. These results suggest that AKP-Vm appears to be a typical alkaline protease. Various divalent cations and protease inhibitors were also tested for their effects on AKP-Vm activity (Table II). Divalent cations such as $\mathrm{Mg}^{2+}$ and $\mathrm{Zn}^{2+}$ showed not so significant effects on AKP-Vm activity; however, $\mathrm{Ni}^{2+}, \mathrm{Mn}^{2+}$ and $\mathrm{Cu}^{2+}$ exhibited an inhibitory effect on AKP-Vm activity at different levels. $\mathrm{Cu}^{2+}$ showed a strong inhibitory effect on the enzyme activity with $\sim 70.1 \%$ of the enzyme activity inhibited by $1 \mathrm{mM}$ of
$\mathrm{CuCl}_{2}$, compared to that of the non-treated control (Table II). The enzyme activity could be also inhibited by treatments with PMSF and aprotinin (Table II). However, the metalloprotease inhibitors such as EGTA and 1,10-PT had no so significant effects (Table II). These results suggest that AKP-Vm is an enzyme included in the alkaline serine protease family and is not a metalloprotease. In addition, an average of $56 \%$ of the enzyme activity could be inhibited by reducing agents such as $\beta$-mercaptoethanol and DTT (Table II), suggesting that a disulfide bond(s) located in the enzyme may play an important role in maintaining the enzyme activity.

Fibrinogenolytic and fibrinolytic activities of AKP-Vm. AKP-Vm could cleave various plasma proteins, including fibrinogen, plasminogen, plasmin, prothrombin, and thrombin (data not shown). By cleaving prothrombin, the enzyme could make a peptide fragment corresponding to thrombin in size, but there was no detectable thrombin activity, as assayed with a typical chromogenic substrate for thrombin (data not shown). This result suggests that AKP-Vm does not have an ability to activate prothrombin, unlike vEP and the vEP-MO6 proteases of $V$. vulnificus strains $(6,19)$. As with prothrombin, fibrinogen was one of efficient protein substrates for AKP-Vm. The enzyme could cleave all three major chains of fibrinogen, resulting in fibrinogen degrading products (FDPs) (Fig. 4A). The $A \alpha$ and $B \beta$ chains of fibrinogen could be totally degraded by AKP-Vm within 1 and 20 min, respectively (Fig. 4A). However, the $\gamma$-chain of fibrinogen was required for a longer time to be digested by the enzyme (Fig. 4A). Although AKP-Vm could cleave fibrinogen efficiently, there was no occurrence of spontaneous polymerization of fibrin monomers that might be produced from fibrinogen cleavage by AKP-Vm, as judged by turbidity assay (Fig. 4B). In addition, AKP-Vm exhibited a strong protease activity to cleave cross-linked fibrin that was catalyzed by thrombin in the presence of factor XIIIa and fibrinogen (Fig. 4C and D). Both $\alpha$ chain polymers and $\gamma-\gamma$ chains of fibrins were susceptible to cleavage by AKP-Vm, as shown by the fibrin plate assay (Fig. 4D).

\section{Discussion}

In this study, we have purified an alkaline serine protease (named AKP-Vm) from the culture filtrate of V. metschnikovii ATCC700040 cells and characterized the biochemical properties of purified enzyme in terms of substrate specificity and enzyme kinetics.

The purified enzyme showed heat-labile properties under high temperature (Fig. 1A). This heat-induced degradation seemed to be related with enzyme activity, as the native $50 \mathrm{kDa}$ enzyme remained intact when inhibited by $\mathrm{NiCl}_{2}$ and $\mathrm{CuCl}_{2}$ (Fig. 2; Table II). These results suggest that the enzyme can be destabilized under high temperature to acquire nonspecificity that can cleave the enzyme itself. Interestingly, the event does not occur in the presence of $\mathrm{ZnCl}_{2}$ (Fig. 2), even though the divalent cation does not inhibit enzyme activity (Table II). This result also demonstrates that $\mathrm{Zn}^{2+}$ may protect the enzyme from the heat-induced loss of enzymatic specificity by stabilizing the conformation of the enzyme to maintain its intrinsic enzymatic specificity. A similar heat-induced degradation can also be observed with the VSPase protease of 


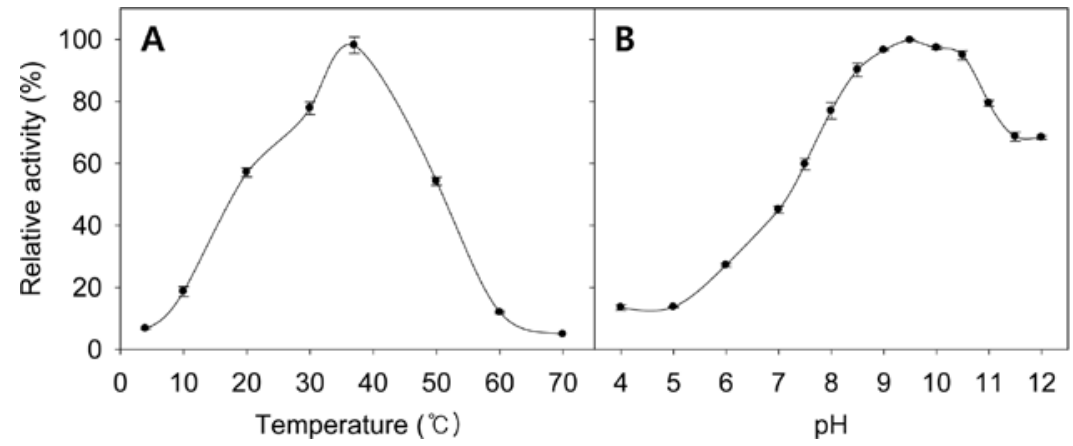

Figure 3. Effects of temperature and $\mathrm{pH}$ on AKP-Vm activity. AKP-Vm activity was assayed with Boc-Val-Pro-Arg- $p$ NA as a substrate under various temperatures (A) or pHs (B) as described in Materials and methods.

A

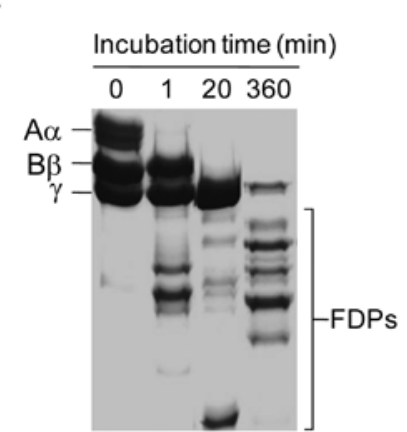

B

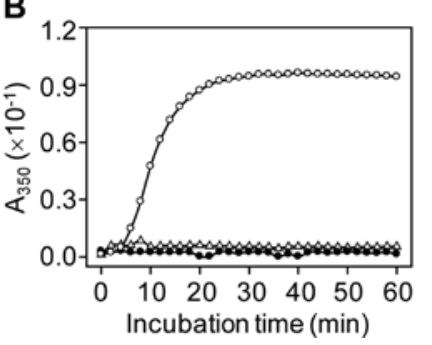

C

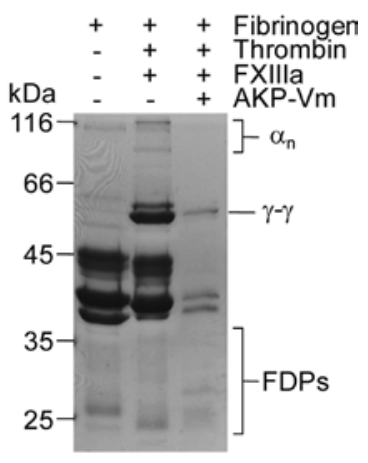

D

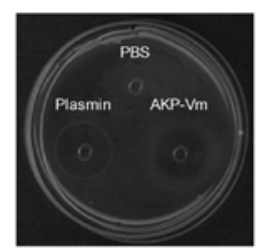

Figure 4. Fibrinogenolytic and fibrinolytic activity of the AKP-Vm enzyme. (A) Fibrinogenolytic activity assay. Fibrinogen $(30 \mu \mathrm{g})$ was incubated with $1 \mu \mathrm{g}$ of $\mathrm{AKP}-\mathrm{Vm}$ at $37^{\circ} \mathrm{C}$ for indicated time periods, and the resulting products were electrophoresed on $12 \%$ SDS-polyacrylamide gel. FDPs means fibrinogen degradation products. (B) Turbidity assay for the spontaneous polymerization of fibrin monomers derived from AKP-Vm-cleaved fibrinogen. In this assay, $90 \mu 1$ of $1 \mathrm{mg} / \mathrm{ml}$ fibrinogen in $25 \mathrm{mM}$ Tris- $\mathrm{HCl}$ buffer (pH 7.5) was mixed with $10 \mu \mathrm{l}$ each of thrombin $(10 \mathrm{U} / \mathrm{ml})$ and AKP-Vm $(50 \mu \mathrm{g} / \mathrm{ml})$, and the increase in absorbance at $350 \mathrm{~nm}$ was then recorded with a 96-well plate reader. $\mathrm{O}$, thrombin plus fibrinogen; $\triangle$, AKP-Vm plus fibrinogen; $\bullet$, fibrinogen only. (C) Fibrinolytic activity assay. Cross-linked fibrin formed by thrombin in the presence of fibrinogen and factor XIIIa (FXIIIa) was incubated with $0.5 \mu \mathrm{g}$ of $\mathrm{AKP}-\mathrm{Vm}$ for $5 \mathrm{~min}$ at $37^{\circ} \mathrm{C}$, and the reaction products were electrophoresed on $12 \%$ SDS-polyacrylamide gel and stained with Coomassie Brilliant Blue. Symbols + and - represent the addition and the omission, respectively. (D) Fibrinolytic activity of AKP-Vm was also assayed on fibrin plate as described in Materials and methods. Phosphatebuffered saline (PBS), AKP-Vm ( $1 \mu \mathrm{g})$, and plasmin ( 0.5 units) were applied on the fibrin plate, and the plate was incubated at $37^{\circ} \mathrm{C}$ for $12 \mathrm{~h} . \alpha_{\mathrm{n}}$ and $\gamma-\gamma$ represent $\alpha$ chain polymers and $\gamma$ chain dimers, respectively.

Staphylococcus aureus (20). The VSPase protease undergoes auto-degradation when it is incubated at a temperature of $55^{\circ} \mathrm{C}$ or higher, resulting in a complete loss of protein within $10 \mathrm{~min}$ of incubation (20). There is another report that an extracellular metalloprotease called vEP from $V$. vulnificus disappears

completely on the polyacrylamide gel when it is pre-incubated at $75^{\circ} \mathrm{C}(6)$.

There have been a few reports on alkaline proteases secreted by several $V$. metschnikovii strains (15-17). An alkaline serine protease (named AprJ1) shows an amidolytic activity against $\mathrm{N}$-succinyl-Ala-Ala-Pro-Phe- $p \mathrm{NA}$, and its catalytic efficiency $\left(k_{\text {cat }} / K_{\mathrm{M}}\right)$ is estimated to $7.23 \times 10^{8} \mathrm{mM}^{-1} \mathrm{~min}^{-1}(17)$. The AKP-Vm enzyme exhibits substrate specificity against Boc-Val-ProArg- $p$ NA (Table II) and shows much lower catalytic efficiency $\left(0.5 \times 10^{2} \mathrm{mM}^{-1} \mathrm{~min}^{-1}\right)$ than AprJ1. These substrate specificities of the enzymes indicate that AKP-Vm and AprJ1 can cleave peptide bonds at the carboxyl sides of arginine and phenylalanine residues, respectively. These results also suggest that the two proteases are different from each other in terms of substrate specificity and kinetic values. AKP-Vm enzyme is active under alkali condition raging from $\mathrm{pH}$ 8.0-12.0, and the enzyme activity can be inhibited by inhibitors (Table II) such as PMSF and aprotinin that are known as inhibitors for serine proteases (21). These results support the fact that AKP-Vm belongs to the family of alkaline serine proteases.

Fibrino(geno)lytic enzymes have been reported from food bacteria $(22,23)$, pathogenic bacteria (24-26), mushroom (27) as well as snake venom $(28,29)$. $\alpha$-fibrinogenases are often found from snake venoms, and most of them are metalloproteases, which can cleave mainly on the $A \alpha$ and less on both the $B \beta$ and the $\gamma$ chains of fibrinogen subunit chains $(30,31)$. A fibrinogenolytic protease secreted from $V$. vulnificus can also rapidly digest the A $\alpha$ chain of fibrinogen (32) and a metalloprotease from $V$. cholerae has an ability to digest three major chains ( $\alpha, \beta$ and $\gamma$ ) of fibrinogen (33). Generally, the fibrin(ogen)olytic serine proteases preferentially cleave the $\mathrm{B} \beta$ chain of fibrinogen with lower activity towards the A $\alpha$ chain (34). However, an alkaline serine protease AKP-Vm enzyme shows more preference to the $A \alpha$ chain than to $B \beta$ chain in the fibrinogen cleavage (Fig. 4A). Almost all of $A \alpha$ and $B \beta$ chains of fibrinogen can be digested by the enzyme within 20 min (Fig. 4A). Most of $\alpha, \beta$ and $\gamma$ chains of fibrinogen can be digested by the enzyme within $360 \mathrm{~min}$ at the mass ratio (enzyme versus fibrinogen) of 1:480. Together with the fibrinogenolytic activity, AKP-Vm is a unique enzyme, in that it has an ability to cleave cross-linked fibrin polymer and cross-linked fibrin. The enzyme can digest actively $\alpha$ chain polymers as well as $\gamma-\gamma$ chains of the cross-linked fibrins (Fig. 4). Collectively, AKP-Vm can cleave all major chains of fibrinogen, fibrin polymer as well as cross-linked fibrin, 
suggesting that the enzyme has a powerful fibrin(ogen)olytic activity like a few enzymes from $V$. vulnificus $(6,19,33)$.

\section{Acknowledgements}

This study was supported by a research fund from Chosun University, 2007.

\section{References}

1. Wallet F, Tachon M, Nseir S, Courcol RJ and Roussel-Delvallez M: Vibrio metschnikovii pneumonia. Emerg Infect Dis 11: 1641-1642, 2005.

2. Chowdhury MA, Miyoshi S and Shinoda S: Vascular permeability enhancement by Vibrio mimicus protease and the mechanisms of action. Microbiol Immunol 35: 1049-1058, 1991.

3. Miyoshi S and Shinoda S: Role of the protease in the permeability enhancement by Vibrio vulnificus. Microbiol Immunol 32: 1025-1032, 1988.

4. Sakata Y, Akaike T, Khan MM, et al: Activation of bradykinin generating cascade by Vibrio cholerae protease. Immunopharm 33: 377-379, 1996.

5. Miyoshi S, Sonoda Y, Wakiyama H, et al: An exocellular thermolysin-like metalloprotease produced by Vibrio fluvialis: purification, characterization, and gene cloning. Microb Pathog 33: 127-134, 2002.

6. Chang AK, Kim HY, Park JE, et al: Vibrio vulnificus secretes a broad-specificity metalloprotease capable of interfering with blood homeostasis through prothrombin activation and fibrinolysis. J Bacteriol 187: 6909-6916, 2005.

7. Janda JM: Mucinase activity among selected members of the family Vibrionaceae. Microbios Lett 33: 19-22, 1986.

8. Kwon YT, Kim JO, Moon SY, Yoo YD and Rho HM: Extracellular alkaline protease from alkalophilic Vibrio metschnikovii strain RH530. Biotech Lett 16: 413-418, 1994.

9. Pariente Martin M, Escribano Garaizabal E, Liria Sanchez PJ and Crespo Sanchez MD: Vibrio metschnikovii from a human infected leg ulcer. Rev Inst Med Trop Sao Paulo 50: 311-312, 2008.

10. Hansen W, Freney J, Benyagoub H, Letouzey MN, Gigi J and Wauters G: Severe human infections caused by Vibrio metschnikovii. J Clin Microbiol 31: 2529-2530, 1993.

11. Magalhaes V, Branco A, de Andrade Lima R and Magalhaes M Vibrio metschnikovii among diarrheal patients during cholera epidemic in Recife Brazil. Rev Inst Med Trop Sao Paulo 38: 1-3, 1996.

12. Dalsgaard A, Alarcon A, Lanata CF, et al: Clinical manifestations and molecular epidemiology of five cases of diarrhoea in children associated with Vibrio metschnikovii in Arequipa, Peru. J Med Microbiol 45: 494-500, 1996.

13. Linde HJ, Kobuch R, Jayasinghe S, et al: Vibrio metschnikovii, a rare cause of wound infection. J Clin Microbiol 42: 4909-4911, 2004

14. Chung SS, Kim HJ, Shy U, Jin JH and Lee HH: Molecular characterization of gene encoding an extracellular alkaline protease in Vibrio metschnikovii. Biotechnol Lett 23: 1175-1182, 2001.

15. Kwon YT, Moon SY, Kim JO, Kho YH and Rho HM: Characterization of extracelular protease from alkalophilic Vibrio sp. strain RH 530. Kor J Microbiol 30: 501-506, 1992.

16. Kwon YT, Kim JO, Moon SY, Yoo YD and Rho HM: Cloning and characterization of the gene encoding an extracellular alkaline serine protease from Vibrio metschnikovii strain RH530. Gene 152: 59-63, 1995.

17. Jellouli K, Bougatef A, Manni L, et al: Molecular and biochemical characterization of an extracellular serine-protease from Vibrio metschnikovii J1. J Ind Microbiol Biotechnol 36: 939-948, 2009.
18. Laemmli UK: Cleavage of structural proteins during the assembly of the head of bacteriophage T4. Nature 227: 680-685, 1970.

19. Kwon JY, Chang AK, Park JE, Shin SY, Yoon SM and Lee JS: Vibrio extracellular protease with prothrombin activation and fibrinolytic activities. Int J Mol Med 19: 157-163, 2007.

20. Park JW, Park JE, Park JK and Lee JS: Purification and biochemical characterization of a novel glutamyl endopeptidase secreted by a clinical isolate of Staphylococcus aureus. Int J Mol Med 27: 637-645, 2011.

21. Matsuzawa H, Tokugawa K, Hamaoki M, et al: Purification and characterization of aqualysin I (a thermophilic alkaline serine protease) produced by Thermus aquaticus YT-1. Eur J Biochem 171: 441-447, 1988.

22. Hwang KJ, Choi KH, Kim MJ, Park CS and Cha J: Purification and characterization of a new fibrinolytic enzyme of Bacillus licheniformis KJ-31, isolated from Korean traditional Jeot-gal. J Microbiol Biotechnol 17: 1469-1476, 2007.

23. Kim GM, Lee AR, Lee KW, et al: Characterization of a $27 \mathrm{kDa}$ fibrinolytic enzyme from Bacillus amyloliquefaciens $\mathrm{CH} 51$ isolated from cheonggukjang. J Microbiol Biotechnol 19: 997-1004, 2009.

24. Balaraman K and Prabakaran G: Production and purification of a fibrinolytic enzyme (thrombinase) from Bacillus sphaericus. Indian J Med Res 126: 459-464, 2007.

25. Fricke B, Parchmann O, Kruse K, Rucknagel P, Schierhorn A and Menge S: Characterization and purification of an outer membrane metalloproteinase from Pseudomonas aeruginosa with fibrinogenolytic activity. Biochim Biophys Acta 1454: 236-250, 1999.

26. Imamura T, Nitta H, Wada Y, Kobayashi $H$ and Okamoto K: Impaired plasma clottability induction through fibrinogen degradation by ASP, a serine protease released from Aeromonas sobria. FEMS Microbiol Lett 284: 35-42, 2008.

27. Kim JS, Sapkota K, Park SE, et al: A fibrinolytic enzyme from the medicinal mushroom Cordyceps militaris. J Microbiol 44: 622-631, 2006.

28. Bernardes CP, Santos-Filho NA, Costa TR, et al: Isolation and structural characterization of a new fibrin(ogen)olytic metalloproteinase from Bothrops moojeni snake venom. Toxicon 51: 574-584, 2008.

29. Koh YS, Chung KH and Kim DS: Biochemical characterization of a thrombin-like enzyme and a fibrinolytic serine protease from snake (Agkistrodon saxatilis) venom. Toxicon 39: 555-560, 2001.

30. Xiao R, Li QW, Perrett S and He RQ: Characterisation of the fibrinogenolytic properties of the buccal gland secretion from Lampetra japonica. Biochimie 89: 383-392, 2007.

31. Huang KF, Hung CC, Pan FM, Chow LP, Tsugita A and Chiou SH: Characterization of multiple metalloproteinases with fibrinogenolytic activity from the venom of Taiwan habu (Trimeresurus mucrosquamatus): protein microsequencing coupled with cDNA sequence analysis. Biochem Biophys Res Commun 216: 223-233, 1995.

32. Miyoshi S, Narukawa H, Tomochika K and Shinoda S: Actions of Vibrio vulnificus metalloprotease on human plasma proteinaseproteinase inhibitor systems: a comparative study of native protease with its derivative modified by polyethylene glycol. Microbiol Immunol 39: 959-966, 1995.

33. Vaitkevicius K, Rompikuntal PK, Lindmark B, Vaitkevicius R, Song T and Wai SN: The metalloprotease PrtV from Vibrio cholerae. FEBS J 275: 3167-3177, 2008.

34. Markland FS Jr: Snake venom fibrinogenolytic and fibrinolytic enzymes: an updated inventory. Thromb Haemost 79: 668-674, 1998. 